Original

\title{
Close Relation of Transforming Growth Factor- $\alpha$ Positive Hepatic Foci to Hepatocellular Tumor Development in the Rat
}

\author{
Seiko Tamano ${ }^{1}$, Mayumi Kawabe ${ }^{1}$, Toshio Ichihara ${ }^{1}$, Akihiro Hagiwara ${ }^{1}$, \\ Masashi Sano ${ }^{1}$, Makoto Asamoto ${ }^{2}$, and Tomoyuki Shirai ${ }^{2}$ \\ ${ }^{1}$ DIMS Institute of Medical Science, Inc., 64 Goura Nishiazai, Azai-cho, Ichinomiya 491-0113, Japan \\ 2 Department of Experimental Pathology and Tumor Biology, Nagoya City University Graduate School of Medical \\ Sciences, 1 Kawasumi, Mizuho-cho, Mizuho-ku, Nagoya 467-8601, Japan
}

\begin{abstract}
The question of whether transforming growth factor- $\alpha$ (TGF- $\alpha$ ) might be a useful marker of preneoplastic lesions during hepatocarcinogenesis was investigated using a medium-term liver carcinogenesis bioassay (Ito test) extended to 50 weeks. Male F344 rats, 6 weeks of age, received a single i.p. injection of $200 \mathrm{mg} / \mathrm{kg}$ diethylnitrosamine (DEN), then after 2 weeks, the animals were divided into four groups. Groups 1 and 2 were maintained on tap water supplemented with $10 \mathrm{ppm}$ of N-nitrosomorpholine (NMOR), a genotoxic carcinogen, for 48 or 6 weeks, respectively. Animals in Group 3 were maintained on basal diet and tap water ad libitum as controls. Group 4 was included as the vehicle control and was maintained until experimental week 50. Two-thirds partial hepatectomy was performed on all rats at the end of week 3 of the experiment. Histopathology and immunohistochemical investigations of glutathione Stransferase placental form (GST-P) and TGF- $\alpha$ of the liver were performed sequentially at experimental weeks 8,12 , 20,35 and 50. The numbers of TGF- $\alpha$ positive lesions were significantly lower than those of GST-P positive foci at all experimental time points. In contrast, the mean size values of TGF- $\alpha$ positive liver lesions in the continuous and 6week treatments of DEN/NMOR, and the DEN alone protocol, were larger than those of their GST-P positive counterparts from week 35. Bromodeoxyuridine (BrdU) labeling indices for TGF- $\alpha$ positive foci and hepatocellular adenomas at week 20 were clearly higher than those for TGF- $\alpha$ negative lesions. In conclusion, the overexpression of TGF- $\alpha$ can be immunohistochemically detected in large hepatocellular lesions demonstrating increased levels of DNA synthesis. Therefore TGF- $\alpha$ may be a marker of a relatively late, progression stage of hepatocarcinogenesis.

(J Toxicol Pathol 2006; 19: 99-106)
\end{abstract}

Key words: transforming growth factor- $\alpha$ (TGF- $\alpha$ ), F344 rat, hepatocarcinogenesis, medium-term liver carcinogenesis bioassay

\section{Introduction}

Transforming growth factor- $\alpha$ (TGF- $\alpha$ ), has been clearly shown to be involved in normal cell development, wound healing and the malignant transformation of cells ${ }^{1-3}$. Synthesized as a $160-\mathrm{kDa}$ membrane-spanning precursor, the more active 50 -amino acid mature form is released from the cell surface by proteolytic cleavage ${ }^{4-7}$. TGF- $\alpha$ positively regulates cell proliferation by means of paracrine or autocrine stimulation ${ }^{8,9}$ via binding to epidermal growth factor (EGF) receptors on the cell surface. In the liver, TGF$\alpha$ gene expression is regulated during development. It is depressed in the adult liver, and enhanced in regenerating

Received: 24 December 2005, Accepted: 10 May 2006

Mailing address: Seiko Tamano, DIMS institute of Medical Science,

Inc., 64 Goura Nishiazai, Azai-cho, Ichinomiya 491-0113, Japan

TEL: 81-586-51-1201 FAX: 81-586-51-5634

E-mail: tamano@dims.co.jp liver and hepatocytes proliferating in culture ${ }^{8-10}$. Rat liver cell lines obtained from experimentally induced hepatocellular carcinomas secrete substantial amounts of TGF- $\alpha^{5}$, and urinary excretion of TGF- $\alpha$ is known to be elevated in some patients with hepatocellular carcinomas ${ }^{11}$.

TGF- $\alpha$ transgenic mice, produced to clarify functions of TGF- $\alpha^{12-18}$, demonstrate enhanced development of hepatocellular carcinomas with diethylnitrosamine initiation and phenobarbital promotion, possibly through a mechanism of increased hepatocyte proliferation in precancerous lesions (alteration foci and adenomas) ${ }^{19}$. Overexpression of TGF- $\alpha$ has been linked with elevated hepatocyte proliferation and hepatocarcinogenesis in both humans and rats ${ }^{20,21}$, especially in the progression stage ${ }^{22-25}$, and there is evidence of its mechanistic role during hepatocarcinogenesis ${ }^{26,27}$.

Initiated hepatocytes and early preneoplastic foci are well known to be characterized by alteration of the normal phenotype, and pronounced upregulation of the glutathione 


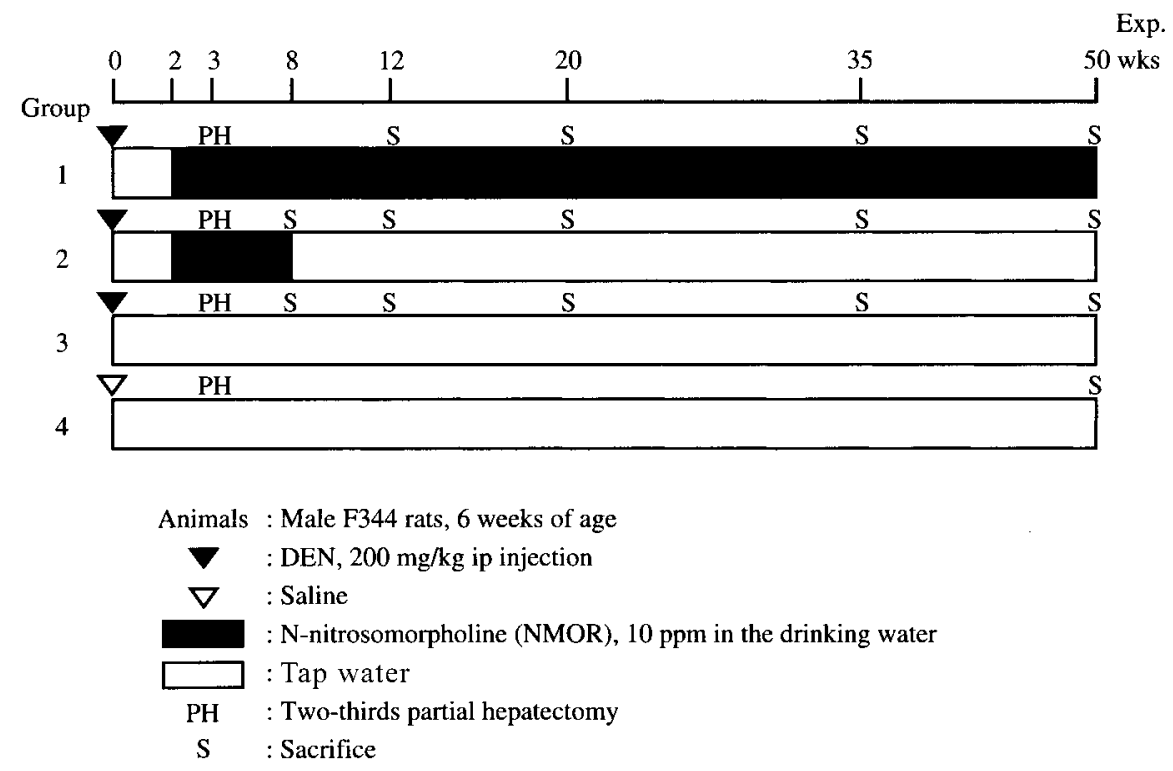

Fig. 1. Experimental Design.

S-transferase placental form (GST-P) which allows ready recognition of them in tissue sections ${ }^{28}$. GST-P, which is an isozyme of GST contributing to the phase II detoxification enzyme, is induced in preneoplastic and neoplastic liver lesions. An epigenetic rather than a genetic mechanism accounts for the induction of GST-P in hepatocytes ${ }^{29}$, and therefore, this enzyme has been extensively used for basic analysis of rat liver carcinogenesis ${ }^{30}$.

In the present study, the relation between TGF- $\alpha$ expression and GST-P positive lesions was examined in rats treated with a representative genotoxic hepatocarcinogen, $\mathrm{N}$ nitrosomorpholine (NMOR). The primary aim was to determine whether TGF- $\alpha$ might be a useful marker for the subset of preneoplastic lesions most likely to give rise to adenomas and carcinomas.

\section{Materials and Methods}

\section{Chemicals}

Diethylnitrosamine (DEN) and N-nitrosomorpholine (NMOR) were obtained from Tokyo Chemical Industry Co. Ltd., Tokyo, Japan.

\section{Animals and maintenance}

Male F344/DuCrj rats, 5 weeks of age, were purchased from Charles River Japan, Inc., Atsugi, Japan, and housed five to a polycarbonate cage with hardwood Beta chips (Northeastern Product Corp., Warrensburg, NY) for bedding. The animals were supplied with food (Oriental MF, Oriental Yeast Co. Ltd., Tokyo, Japan) and tap water ad libitum and the room temperature and relative humidity were controlled at $22 \pm 2{ }^{\circ} \mathrm{C}$ and $55 \pm 10 \%$, respectively. Fluorescent lighting provided a 12-hr light/dark cycle. The animals were observed daily for abnormalities, and body weights and food and water consumptions were recorded once a week until 14 weeks and then every 4 weeks until the end of the experiment.

After a one-week quarantine period, a total of 101 F344/DuCrj rats were randomly divided into 4 groups. The experimental design is illustrated in Fig. 1. Ninety-three rats (groups 1 to 3) were treated intraperitoneally with DEN at a dose of $200 \mathrm{mg} / \mathrm{kg}$ body weight and given basal diet for the first 2 weeks. Then the animals in groups 1 and 2 were maintained on tap water supplemented with 10 ppm NMOR for 48 or 6 weeks, respectively, while those in Group 3 were given basal diet and tap water ad libitum. The remaining 8 rats (Group 4) received a saline i.p. injection followed by unsupplemented water. Two-thirds partial hepatectomy was performed on all rats at the end of week 3 of the experiment. Five rats from groups 2 and 3 were sacrificed by exsanguination from the abdominal aorta under ether anesthesia and necropsied at the end of week 8, then 4 or 5 rats from each group, except Group 4, were similary sacrificed at the ends of weeks 12, 20 and 35, and 8 to 11 rats of each group at the end of week 50. At necropsy, final body weights after fasting over night were recorded and the livers were removed and weighed. Each liver lobe was cut into 2to $3-\mathrm{mm}$ thick sections with a razor blade, fixed in $10 \%$ phosphate-buffered formalin and embedded in paraffin.

\section{Histopathological and immunohistochemical procedures}

Three serial sections through the liver from each animal were stained with hematoxylin and eosin (H\&E), and then immunohistochemically stained for glutathione Stransferase placental form (GST-P) and TGF- $\alpha$ with anti-rat GST-P rabbit serum (Medical \& Biological Laboratories Co., Ltd, Nagoya, Japan) at 1:2000 dilution, and anti-human TGF- $\alpha$ mouse serum (Oncogene Research Products, Boston, MA) at 1:500 dilution. The avidin-biotin peroxidase 


\section{DEN/NMOR}

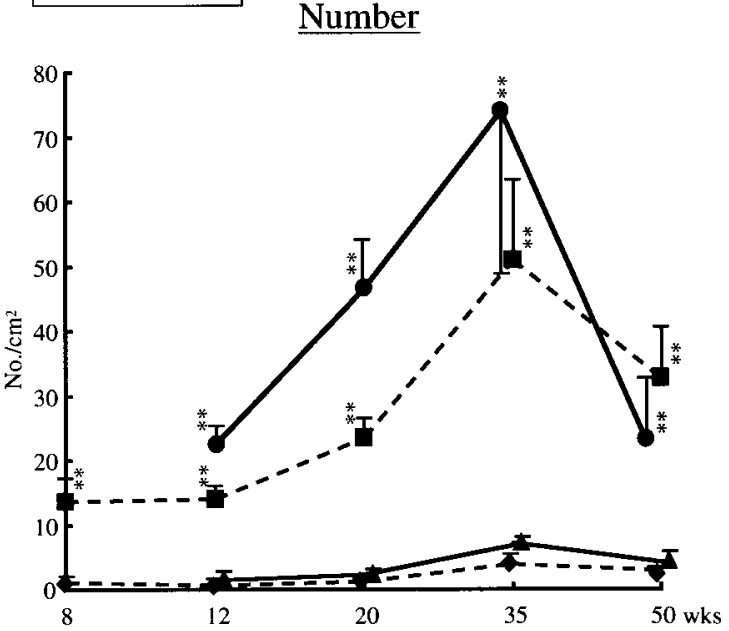

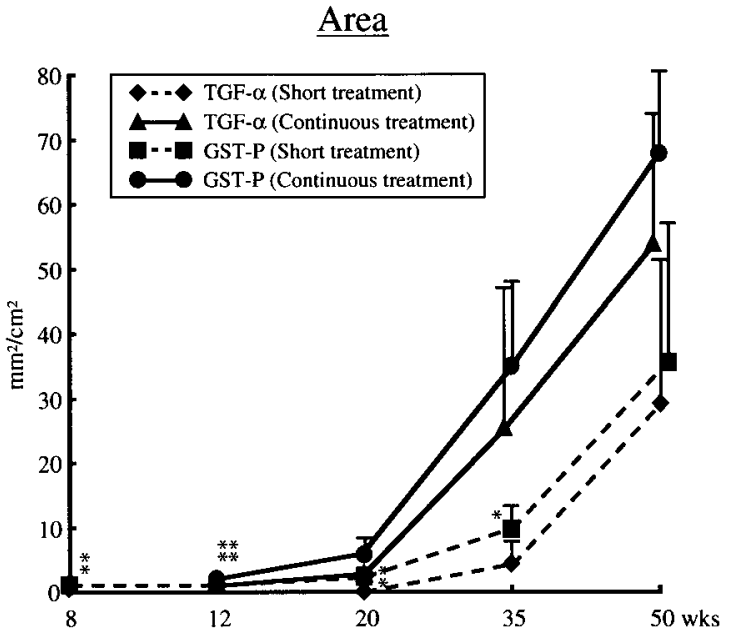

Fig. 2. Numbers and areas of GST-P and TGF- $\alpha$ positive liver lesions in livers of DEN-initiated rats given NMOR. $*, * *$ : Significantly different from TGF- $\alpha$ positive lesions at $\mathrm{P}<0.05,0.01$, respectively.
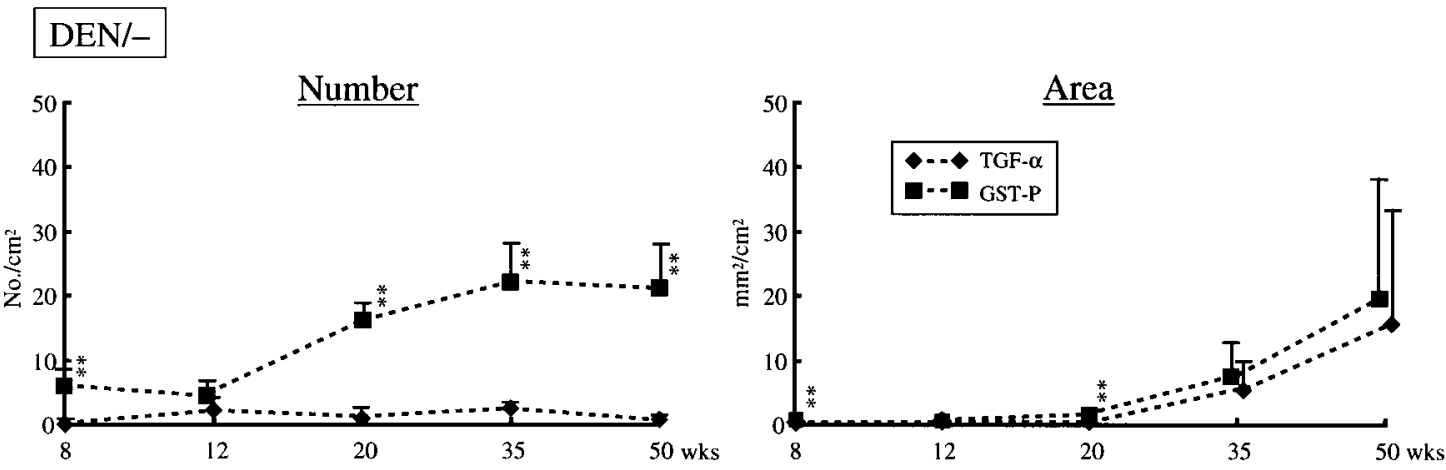

Fig. 3. Numbers and areas of GST-P and TGF- $\alpha$ positive liver lesions in livers of DEN-initiated rats **: Significantly different from TGF- $\alpha$ positive lesions at $\mathrm{P}<0.01$.

complex (ABC) technique was employed using a rabbit Vectastain Elite ABC kit (Vector Laboratories, Burlingame, CA) and GST-P and TGF- $\alpha$ were visualized using 3,3'diaminobenzidine tetrahydrochloride (DAB) and new fucsin, respectively. Representative paraffin liver sections were stained doubly for GST-P and TGF- $\alpha$.

\section{Image analysis}

Liver lesions were classified according to criteria defined previously ${ }^{31}$. GST-P or TGF- $\alpha$ positive lesions were traced using a color image processor (SPICA-II; Nippon Avionics Co. Ltd., Tokyo, Japan), and their numbers and areas per $\mathrm{cm}^{2}$ were measured.

\section{Labeling indices for bromodeoxyuridine (BrdU)}

During week 20, Alzet osmolar infusion pumps (Alza Corporation, Palo Alto, CA) filled with 200-300 $\mu \mathrm{g}$ of BrdU were implanted intraperitoneally into 4 rats of Group 1 (continuous NMOR treatment, 3 days before sacrifice. Sections from the livers of these rats were also immunohistochemically stained for BrdU by the avidinbiotin peroxidase complex $(\mathrm{ABC})$ technique, using a mouse Vectastain Elite ABC kit (Vector Laboratories, Burlingame, CA). A mouse anti-bromodeoxyuridine monoclonal antibody at 1:2000 dilution (DakoCytomation, Denmark) was used as the antibody.

All experimental procedures were performed in accordance with the in-house guidelines for the Care and Use of Laboratory Animals at the DIMS Institute of Medical Science, Inc.

\section{Statistical analysis}

Mean values \pm SD for body weights, liver-to-body weight ratios, BrdU labeling indices and liver lesions were assessed for significant differences between test and control groups by the two-tailed Student's $t$-test. 
Table 1. Mean Sizes of GST-P and TGF- $\alpha$ Positive Liver Lesions

\begin{tabular}{|c|c|c|c|c|c|}
\hline \multirow{2}{*}{ Group } & \multirow{2}{*}{ Treatment } & \multirow{2}{*}{$\begin{array}{l}\text { NMOR Treatment } \\
\text { period (weeks) }\end{array}$} & \multirow{2}{*}{$\begin{array}{l}\text { Observation } \\
\text { time (weeks) }\end{array}$} & \multicolumn{2}{|c|}{ Mean size of liver lesions $\left(\mathrm{mm}^{2}\right)$} \\
\hline & & & & GST-P positive & TGF- $\alpha$ positive \\
\hline \multirow[t]{4}{*}{1} & $\mathrm{DEN} \rightarrow \mathrm{NMOR}+\mathrm{PH}$ & 10 & 12 & $0.07 \pm 0.01^{\mathrm{b}}(5)$ & $0.11 \pm 0.12$ \\
\hline & (Continuous treatment) & 18 & 20 & $0.12 \pm 0.07(4)$ & $0.57 \pm 0.66(4)$ \\
\hline & & 33 & 35 & $0.57 \pm 0.41(5)$ & $3.46 \pm 3.39(5)$ \\
\hline & & 48 & 50 & $4.65 \pm 5.71(13)^{\mathrm{a}}$ & $15.96 \pm 12.89(13)^{\mathrm{a} *}$ \\
\hline \multirow[t]{5}{*}{2} & $\mathrm{DEN} \rightarrow \mathrm{NMOR}+\mathrm{PH}$ & 6 & 8 & $0.07 \pm 0.01(5)$ & $0.06 \pm 0.04(5)$ \\
\hline & (Short treatment) & 6 & 12 & $0.08 \pm 0.02$ & $0.06 \pm 0.04$ \\
\hline & & 6 & 20 & $0.10 \pm 0.01$ & $0.06 \pm 0.04(5)$ \\
\hline & & 6 & 35 & $0.21 \pm 0.11(5)$ & $1.67 \pm 1.97(5)$ \\
\hline & & 6 & 50 & $1.58 \pm 1.70(9)$ & $15.97 \pm 14.40(9)^{* *}$ \\
\hline \multirow[t]{5}{*}{3} & $\mathrm{DEN} \rightarrow \mathrm{PH}$ & & 8 & $0.07 \pm 0.02(5)$ & $0.06 \pm 0.01$ \\
\hline & & & 12 & $0.06 \pm 0.01$ & $0.05 \pm 0.01$ \\
\hline & & & 20 & $0.10 \pm 0.03$ & $0.06 \pm 0.01$ \\
\hline & & & 35 & $0.35 \pm 0.31(5)$ & $2.22 \pm 2.52(5)$ \\
\hline & & & 50 & $1.13 \pm 1.27(10)$ & $23.88 \pm 34.41(9)$ \\
\hline 4 & Saline $\rightarrow \mathrm{PH}$ & & 50 & $0.04 \pm 0.01(5)$ & $0 \pm 0(8)$ \\
\hline
\end{tabular}

*, **: Significantly different from GST-P positive liver lesions at $\mathrm{P}<0.05,0.01$, respectively.

a: Includes two moribund animals.

b: mean $\pm \mathrm{SD}$.

Numbers of rats examined are given in parentheses.

Table 2. BrdU Labeling Indices for Hepatic Lesions at Week 20 in Livers of Rats Treated with DEN/NMOR (Group 1)

\begin{tabular}{|c|c|c|c|}
\hline \multirow{2}{*}{$\begin{array}{c}\text { Surrounding } \\
\text { normal hepatocytes }\end{array}$} & \multicolumn{2}{|c|}{ Preneoplastic lesions } & \multirow{2}{*}{$\begin{array}{c}\text { Hepatocellular adenoma } \\
\text { GST-P }(+) / \text { TGF- } \alpha(+)\end{array}$} \\
\hline & GST-P(+)/TGF- $\alpha(-)$ & GST-P(+)/TGF- $\alpha(+)$ & \\
\hline $0.40 \pm 0.08(4)^{\mathrm{a}, \mathrm{c} * *}$ & $0.69 \pm 0.74(13)^{\mathrm{b}}$ & $3.70 \pm 1.56(2)^{\mathrm{b}}$ & $14.25 \pm 16.48(2)^{\mathrm{b}}$ \\
\hline
\end{tabular}

**: Significantly different from the GST-P $(+) /$ TGF- $\alpha(-)$ preneoplastic lesions at $\mathrm{P}<0.01$.

a: Number of liver samples investigated are given in parenthesis.

b: Numbers of liver lesions investigated are given in parentheses.

c: mean \pm SD.

\section{Results}

\section{Body weights and liver weights}

Mean body weights of rats treated with DEN/NMOR in both Groups 1 and 2 were lower than those of the control Group 3, at week 50 (data not shown).

Liver weights of rats treated with DEN/NMOR in Group 1 (continuous NMOR treatment) were greater than the values of Group 3, while those for rats treated with DEN/ NMOR for only 6 weeks, Group 2, were increased at weeks 8 and 12 (data not shown).

Changes in GST-P and TGF- $\alpha$ positive liver lesions

Data for the numbers and areas of GST-P and TGF- $\alpha$ positive liver lesions are illustrated in Figs. 2 and 3. The numbers of GST-P positive lesions increased until week 35, but were in decline at week 50 in the groups receiving DEN/ NMOR as well as DEN alone. Changes in the numbers of TGF- $\alpha$ positive lesions were similar to those of GST-P positive lesions but the absolute values were significantly lower than those of GST-P positive foci at all experimental time points. The areas of both GST-P and TGF- $\alpha$ positive lesions increased throughout in a time-dependent manner. Significant differences in areas between GST-P and TGF- $\alpha$ positive lesions were not apparent in the groups receiving DEN/NMOR and DEN alone.

The mean sizes of GST-P and TGF- $\alpha$ positive liver lesions are given in Table 1. The mean size values for TGF$\alpha$ positive liver lesions were larger than those for their GST$\mathrm{P}$ positive counterparts from weeks 12 or 35 to the end of experiment in Groups 1 and 2, which were given DEN/ NMOR continuously and for 6 weeks, respectively. They were also larger at all time points, with clear difference at weeks 35 and 50 in the group receiving DEN alone (Group $3)$.

\section{BrdU labeling indices}

BrdU labeling indices in hepatic lesions are given in Table 2. At week 20, values for TGF- $\alpha$ positive preneoplastic lesions and hepatocellular adenomas induced by the regime of DEN/NMOR (Group 1) were clearly higher than those for TGF- $\alpha$ negative lesions. 

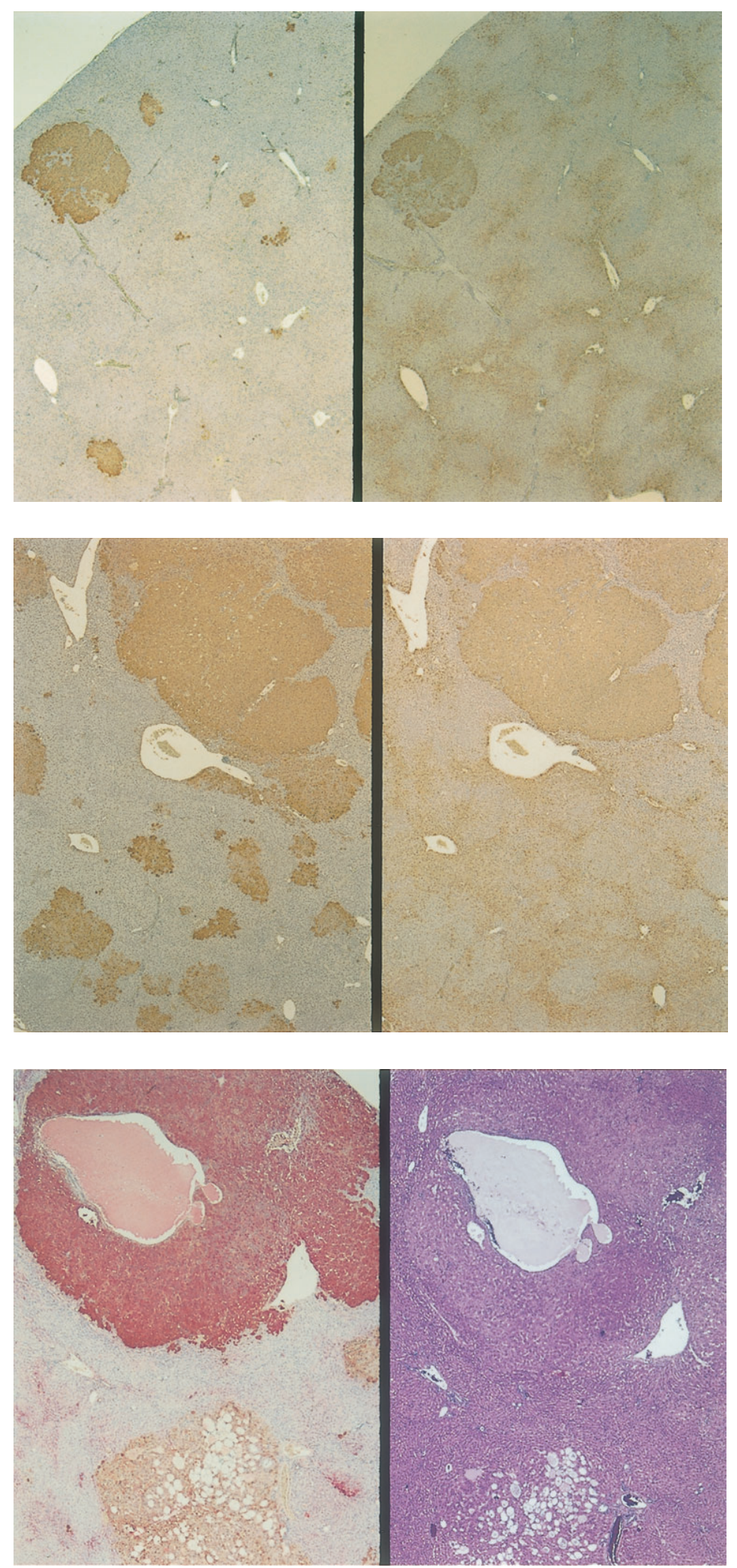

Fig. 4. Immunohistochemical findings for GST-P positive lesions(left) and TGF- $\alpha$ positive lesions (right) in the liver of a Group 1 rat at experimental week 12 $(\times 18)$.

Fig. 5. Immunohistochemical findings for GST-P positive lesions (left) and TGF- $\alpha$ positive lesions (right) in the liver of a Group 1 rat at experimental week 35 $(\times 18)$.

Fig. 6. Immunohistochemical findings of GST-P and TGF$\alpha$ double staining of liver lesions (left) and histopathological findings (right, $\mathrm{H} \& \mathrm{E}$ staining) in the liver of a Group 2 rat at experimental week 50 $(\times 58)$.

\section{TGF- $\alpha$ expression in liver lesions}

TGF- $\alpha$ was found to be expressed in centrilobular areas on the cell membranes of normal hepatocytes, as previously reported $^{13}$ (Figs. 4 and 5). Percentage incidences of TGF- $\alpha$ overexpressing liver lesions are presented in Table 3 . The values were $2.2-13.2 \%$ of GST-P positive eosinophilic foci, overall. TGF- $\alpha$ overexpression in the adenomas and carcinomas was much higher with incidences of 69-100\%.

Sequential data for incidences of liver tumors in the rats are given in Table 4. Continuous treatment with DEN/ 
Table 3. Percentages of TGF- $\alpha$ Staining Liver Lesions Positive for GST-P

\begin{tabular}{|c|c|c|c|c|c|c|}
\hline \multirow{2}{*}{ Group } & \multirow{2}{*}{ Treatment } & \multirow{2}{*}{$\begin{array}{l}\text { NMOR Treatment } \\
\text { period (weeks) }\end{array}$} & \multirow{2}{*}{$\begin{array}{l}\text { Observation } \\
\text { time (weeks) }\end{array}$} & \multicolumn{3}{|c|}{ Liver lesions } \\
\hline & & & & Eosinophilic foci & Hepatocellular adenomas $^{\mathrm{a}}$ & Carcinomas \\
\hline \multirow[t]{4}{*}{1} & $\mathrm{DEN} \rightarrow \mathrm{NMOR}+\mathrm{PH}$ & 10 & 12 & $6.4 \pm 5.6^{\mathrm{f}}(5)^{\mathrm{b}}$ & - & - \\
\hline & (Continuous treatment) & 18 & 20 & $4.3 \pm 2.6(4)$ & $100(2)^{\mathrm{c}}$ & - \\
\hline & & 33 & 35 & $8.4 \pm 2.7(5)$ & $82 \pm 29(5)$ & $100(5 / 5)^{\mathrm{d}}$ \\
\hline & & 48 & 50 & $12.7 \pm 6.2(13)^{\mathrm{e}}$ & $88 \pm 23(12)$ & $89(32 / 36)$ \\
\hline \multirow[t]{5}{*}{2} & $\mathrm{DEN} \rightarrow \mathrm{NMOR}+\mathrm{PH}$ & 6 & 8 & $13.2 \pm 7.2(5)$ & - & - \\
\hline & (Short treatment) & 6 & 12 & $4.2 \pm 4.5(5)$ & - & - \\
\hline & & 6 & 20 & $5.0 \pm 2.5(5)$ & - & - \\
\hline & & 6 & 35 & $5.4 \pm 2.2(5)$ & $75 \pm 32(4)$ & - \\
\hline & & 6 & 50 & $5.4 \pm 3.0(9)$ & $100(8)$ & $100(7 / 7)$ \\
\hline \multirow[t]{5}{*}{3} & $\mathrm{DEN} \rightarrow \mathrm{PH}$ & & 8 & $4.8 \pm 6.7(5)$ & - & - \\
\hline & & & 12 & $10.8 \pm 19.1(5)$ & - & - \\
\hline & & & 20 & $7.6 \pm 7.2(5)$ & - & - \\
\hline & & & 35 & $10.8 \pm 4.7(5)$ & $83 \pm 29(3)$ & - \\
\hline & & & 50 & $2.2 \pm 2.1(10)$ & $69 \pm 46(8)$ & - \\
\hline 4 & Saline $\rightarrow \mathrm{PH}$ & & 50 & $0(8)$ & & \\
\hline
\end{tabular}

a: All of eosinophilic type.

b: Number of animals examined.

c: Number of adenoma-bearing animals.

d: Number of carcinomas.

e: Including two moribund animals.

f: mean \pm SD.

Table 4. Numbers of Rats Bearing Liver Tumors (Percentages)

\begin{tabular}{|c|c|c|c|c|c|c|}
\hline Group & Treatment & NMOR Treatment & $\begin{array}{l}\text { Observation } \\
\text { time (weeks) }\end{array}$ & No. of rats & Hepatocellular & Hepatocellular \\
\hline \multirow[t]{3}{*}{1} & $\mathrm{DEN} \rightarrow \mathrm{NMOR}+\mathrm{PH}$ & 18 & 20 & 4 & $2(50)$ & 0 \\
\hline & (Continuous treatment) & 33 & 35 & 5 & $5(100)$ & $3(60)$ \\
\hline & & 48 & 50 & $13^{\mathrm{b}}$ & $13(100)$ & $13^{\mathrm{c}}(100)$ \\
\hline \multirow[t]{2}{*}{2} & $\mathrm{DEN} \rightarrow \mathrm{NMOR}+\mathrm{PH}$ & 6 & 35 & 5 & $5(100)$ & 0 \\
\hline & (Short treatment) & 6 & 50 & 9 & $8(89)$ & $5(56)$ \\
\hline \multirow[t]{2}{*}{3} & $\mathrm{DEN} \rightarrow \mathrm{PH}$ & 0 & 35 & 5 & $3(60)$ & 0 \\
\hline & & 0 & 50 & 10 & $8(80)$ & 0 \\
\hline 4 & Saline $\rightarrow \mathrm{PH}$ & 0 & 50 & 8 & 0 & 0 \\
\hline
\end{tabular}

a: Including carcinoma within adenoma and hepatocholangiocellular carcinomas.

b: Includes two moribund animals.

c: Metastasis to the lung (6 rats).

NMOR induced hepatocellular adenomas at weeks 20 or more and hepatocellular carcinomas (HCCs) at weeks 35 or more (Group 1), while adenomas were noted at weeks 35 or more and HCCs at week 50 in the short treatment group (Group 2). Adenomas were observed in control rats treated with DEN alone, Group 3, at weeks 35 or more, but HCCs did not develop.

\section{Discussion}

In the present study on TGF- $\alpha$ overexpression in preneoplastic and neoplastic lesions induced by a two-stage hepatocarcinogenesis bioassay system with partial hepatectomy, an association with more advanced lesions was evident. This results agrees with the proposed stimulation potential of TGF- $\alpha$ on the progression stage in rat hepatocarcinogenesis ${ }^{25}$. The numbers of TGF- $\alpha$ positive lesions were significantly lower than those of GST-P positive counterparts, however, their areas were comparable because the large preneoplastic foci (eosinophilic), adenomas (eosinophilic) and carcinomas, and especially the latter two, tended to have strong TGF- $\alpha$ expression. In the early stage of liver carcinogenesis, in contrast, the rate for TGF- $\alpha$ positive foci was only $2.2-13.2 \%$ of that for GST-P positive foci, a result which is in agreement with a previous report $^{32,33}$.

The TGF- $\alpha$ overexpressing populations were also found to exhibit elevated cell proliferation activity, because BrdU labeling indices for TGF- $\alpha$ positive lesions were higher than those for the GST-P positive population. These 
results strongly suggest that these lesions overexpressing TGF- $\alpha$ are more likely to progress to neoplasms. TGF- $\alpha$ induction is known to be mediated by an autocrine growth stimulatory loop and it is documented that TGF- $\alpha$ can act in concert with chemical carcinogens to promote hepatocarcinogenesis ${ }^{18,19}$.

In conclusion, overexpression of TGF- $\alpha$ can be immunohistochemically detected in large preneoplastic and neoplastic hepatocellular lesions demonstrating increased levels of DNA synthesis. Therefore, it may be involved in a relatively late, progression stage of hepatocarcinogenesis, suggesting the potential use of TGF- $\alpha$ as a marker of hepatocarcinogenesis.

Acknowledgement: This study was supported by the Society for Promotion of Pathology of Nagoya, Japan.

\section{References}

1. Derynck R. Transforming growth factor $\alpha$. Cell. 54: 593595. 1988.

2. Salomon DS, Kim N, Saeki T, and Ciardiello F. Transforming growth factor- $\alpha$ : an oncodevelopmental growth factor. Cancer Cells. 2: 389-397. 1990.

3. Derynck R. The physiology of transforming growth factor$\alpha$. In: Advances in Cancer Research. GF Vande Woude and G Klein (eds). Academic Press, New York. Vol. 58, 27-52. 1992.

4. Ignotz RA, Kelly B, Davis RJ, and Massagué J. Biologically active precursor for transforming growth factor type $\alpha$ released by retrovirally transformed cell. Proc Natl Acad Sci USA. 83: 6307-6311. 1986.

5. Luetteke NC, Michalopoulos GK, Teixid J, Gilmore R, Massague J, and Lee DC. Characterization of high molecular weight transforming growth factor $\alpha$ produced by rat hepatocellular carcinoma cells. Biochemistry. 27: 64876494. 1988.

6. Massagué J. Transforming growth factor-alpha. A model for membrane -anchored growth factors. J Biol Chem. 265: 21393-21396. 1990.

7. Pandiella A and Massagué J. Transforming growth factoralpha. Biochem Soc Trans. 19: 259-262. 1991.

8. Mead JE and Fausto N. Transforming growth factor $\alpha$ may be a physiological regulator of liver regeneration by mean of an autocrine mechanism. Proc Natl Acad Sci USA. 86: 1558-1562. 1989.

9. Fausto N. Growth factors in liver development, regeneration and carcinogenesis. Prog Growth Factor Res. 3: 219-234. 1991.

10. Brown PI, Lam R, Lakshmanan J, and Fisher DA. Transforming growth factor alpha in developing rats. Am J Physiol. 25: E256-E260. 1990.

11. Yeh YC, Tsi JF, Chuang LY, Yeh HW, Tsai JH, Florine DL, and Tam JP. Elevation of transforming growth factor alpha and alphafetoprotein levels in patients with hepatocellular carcinoma. Cancer Res. 47: 896-901. 1987.

12. Jhappan C, Stahle C, Harkins RN, Fausto N, Smith GH, and Merlino GT. TGF $\alpha$ overexpression in transgenic mice induces liver neoplasia and abnormal development of the mammary gland and pancreas. Cell. 61: 1137-1146. 1990.
13. Lee G-H, Merlino G, and Fausto N. Development of liver tumors in transforming growth factor $\alpha$-transgenic mice. Cancer Res. 52: 5162-5170. 1992.

14. Lee LW, Raymond VW, Tsao M-S, Lee DC, Earp HS, and Grisham JW. Clonal cosegregation of tumorigenicity with overexpression of c-myc and transforming growth factor $\alpha$ genes in chemically transformed rat liver epithelial cells. Cancer Res. 51: 5238-5244. 1991.

15. Murakami H, Sanderson ND, Nagy P, Marino PA, Merlino $\mathrm{G}$, and Thorgeirsson SS. Transgenic mouse model for synergistic effects of nuclear oncogenes and growth factors in tumorigenesis: interaction of c-myc and transforming growth factor $\alpha$ in hepatic oncogenesis. Cancer Res. 53: 1719-1723. 1993.

16. Sandgren EP, Luetteke NC, Qiu TH, Palmiter RD, Brinster RL, and Lee DC. Transforming growth factor alpha dramatically enhances onocogene-induced carcinogenesis in transgenic mouse pancreas and liver. Mol Cell Biol. 13: 320-330. 1993.

17. Takagi H, Sharp R, Hammermeister C, Goodrow T, Bradley MO, Fausto N, and Merlino G. Molecular and genetic analysis of liver oncogenesis in transforming growth factor $\alpha$ transgenic mice. Cancer Res. 52: 5171-5177. 1992.

18. Takagi H, Sharp R, Takayama H, Anver MR, Ward JM, and Merlino G. Collaboration between growth factors and diverse chemical carcinogens in hepatocarcinogenesis of transforming growth factor transgenic mice. Cancer Res. 53: 4329-4336. 1993.

19. Tamano S, Merlino GT, and Ward JM. Rapid development of hepatic tumors in transforming growth factor $\alpha$ transgenic mice associated with increased cell proliferation in precancerous hepatocellular lesions initiated by $\mathrm{N}-$ nitrosodiethylamine and promoted by Phenobarbital. Carcinogenesis. 15: 1791-1798. 1994.

20. Harada K, Shiota G, and Kawasaki H. Transforming growth factor-alpha and epidermal growth factor receptor in chronic liver disease and hepatocellular carcinoma. Liver. 19: 318325. 1999.

21. Steinmetz KL and Klaunig JE. Transforming growth factor$\alpha$ in carcinogen-induced F344 rat hepatic foci. Toxicol Appl Pharmacol. 140: 131-145. 1996.

22. Perez-Tomas R, Mayol X, Cullere X, Diaz Ruiz C, and Domingo J. Transforming growth factor-alpha expression in rat experimental hepatocarcinogenesis. Histol Histopathol. 7: 457-462. 1992.

23. Dragan Y, Teeguaeden J, Campbell H, Hsia S, and Pitot H. The quantitation of altered hepatic foci during multistages hepatocarcinogenesis in the rat: Transforming growth factor $\alpha$ expression as a marker for the stage of progression. Cancer Lett. 93: 73-83. 1995.

24. Burr AW, Toole K, Mathew J, Hines JE, Chapman C, and Burt AD. Transforming growth factor-alpha expression is altered during experimental hepatocarcinogenesis. J Pathol. 179: 276-282. 1996.

25. Pitot HC, Dragan YP, Teeguarden J, Hsia S, and Campbell $\mathrm{H}$. Quantitation of multistage carcinogenesis in rat liver. Toxicol Pathol. 24: 119-128. 1996.

26. Tanno $\mathrm{S}$ and Ogawa K. Abundant TGF alpha precursor and EGF receptor expression as a possible mechanism for the preferential growth of carcinogen -induced preneoplastic and neoplastic hepatocytes in rats. Carcinogenesis. 15: 1689-1694. 1994. 
27. Hu Z, Evarts RP, Fujio K, Omori N, Omori M, Marsden ER, and Thorgeirsson SS. Expression of transforming growth factor alpha/epidermal growth factor receptor, hepatocyte growth factor/c-met and acidic fibroblast growth factor/ fibroblast growth factor receptors during hepatocarcinogenesis. Carcinogenesis. 17: 931-938. 1996.

28. Tatematsu M, Mera Y, Inoue T, Satoh K, Sato K, and Ito N. Stable phenotypic expression of glutathione S-transferase placental type and unstable phenotypic expression of $\gamma$ glutamyltransferase in rat liver preneoplastic and neoplastic lesions. Carcinogenesis. 9: 215-220. 1988.

29. Satoh K and Hatayama I. Anomalous elevation of glutathione S-transferase P-form (GST-P) in the elementary process of epigenetic initiation of chemical hepatocarcinogenesis in rats. Carcinogenesis. 23: 11931198. 2002.
30. Ito $\mathrm{N}$, Tamano $\mathrm{S}$, and Shirai $\mathrm{T}$. A medium-term rat liver bioassay for rapid in vivo detection of carcinogenic potential of chemicals. Cancer Sci. 94: 3-8. 2003.

31. Schauer S and Kunze E. In: Pathology of Tumours in Laboratory Animals. Vol. I-Tumurs of the rat, Part 2. VS Turusov (ed), IARC Scientific Publications, Lyon, 41-72, 1987.

32. Kaufmann WK, Zhang Y, and Kaufman DG. Association between expression of transforming growth factor-alpha and progression of hepatocellular foci to neoplasms. Carcinogenesis. 13: 1481-1483. 1992.

33. Kitano M, Ichihara T, Matsuda T, Wanibuchi H, Tamano S, Hagiwara A, Imaoka S, Funae Y, Shirai T, and Fukushima S. Presence of a threshold for promoting effects of Phenobarbital on diethylnitrosamine-induced hepatic foci in the rat. Carcinogenesis. 19: 1475-1480. 1998. 